\title{
Intracellular persistence of enteroaggregative Escherichia coli induces a proinflammatory cytokines secretion in intestinal epithelial T84 cells
}

\author{
Ricardo Luís Lopes BRAGA, Ana Claudia Machado PEREIRA, Andréa Fonseca FERREIRA, \\ Ana Cláudia de Paula ROSA and Wânia Ferraz PEREIRA-MANFRO
}

\begin{abstract}
Background - The competence of enteroaggregative Escherichia coli (EAEC) to adhere to the intestinal epithelium of the host is a key role to the colonization and disease development. The virulence genes are crucial for EAEC pathogenicity during adherence, internalization and persistence in the host. The overwhelming majority of antigen encounters in a host occurs on the intestine surface, which is considered a part of innate mucosal immunity. Intestinal epithelial cells (IECs) can be activated by microorganisms and induce an immune response. Objective - The present study investigated the interaction of invasive EAEC strains with T84 intestinal epithelial cell line in respect to bacterial invasiveness, persistence and cytokines production. Methods - We evaluated intracellular persistence of invasive EAEC strains (H92/3, I49/3 and the prototype 042) and production of cytokines by sandwich ELISA in T84 cells upon 24 hours of infection. Results - The survival rates of the prototype 042 was $0.5 \times 10^{3}$ CFU/ $\mathrm{mL}$ while survival of $\mathrm{I} 49 / 3$ and $\mathrm{H} 92 / 3$ reached $3.2 \times 10^{3} \mathrm{CFU} / \mathrm{mL}$ and $1.4 \times 10^{3} \mathrm{CFU} / \mathrm{mL}$, respectively. Infection with all EAEC strains tested induced significant amounts of IL-8, IL-6 and TNF- $\alpha$ compared to uninfected T84 cells. Conclusion - These data showed that infection by invasive EAEC induce a proinflammatory immune response in intestinal epithelial T84 cells.
\end{abstract}

HEADINGS - Escherichia coli infections. Intestinal mucosa. Epithelial cells. Cytokines.

\section{INTRODUCTION}

Enteroaggregative Escherichia coli (EAEC) were first associated with persistent diarrhea in children in developing world. Since then, it has been widely linked with the acute and persistent diarrhea in infants and children in developing and industrialized countries, also in individuals infected with the human immunodeficiency virus (HIV). Besides, it has been recognized as a significant cause of traveler's diarrhea and in foodborne outbreaks ${ }^{(1)}$. In Brazil, EAEC infection were identified as the most common cause of diarrhea in children younger than five years of age $\mathrm{e}^{(2,3,4)}$

The ability of EAEC to adhere to the intestinal epithelium of the host represents, undoubtedly, a key piece to their subsequent colonization and disease production ${ }^{(5)}$. Clinically, the symptoms may be watery diarrhea, often accompanied by fever, nausea and vomiting ${ }^{(6)}$. The variations of symptoms are due to factors such as genetic susceptibility and immune response of the host, heterogeneity of virulence among strains and the amount of bacteria ingested ${ }^{(7)}$.

EAEC adherence to the human intestinal mucosa requires expression of aggregative adherence fimbriae (AAFs), which promote the formation of a thick biofilm. Mucosal secretion may then be induced by the production of bacterial enterotoxins and cytotoxins $^{(1)}$. After adhering and colonizing, EAEC is able to invade intestinal cells ${ }^{(8,9,10)}$. Thus, the virulence genes are integral for EAEC pathogenicity which are employed by bacteria during adherence, internalization and persistence in the host, as well as mediating mucosal toxicity by induction of inflammatory responses ${ }^{(11)}$.
The overwhelming majority of antigen encounters occur on the intestinal surface, which is considered a part of innate mucosal immunity. Intestinal epithelial cells (IECs) play a significant role in regulating the response to the microbiota through multiple pattern recognition receptors (PRRs) that recognize microbial-associated molecular patterns (MAMPs) and facilitate crosstalk with luminal bacteria and their antigens. Among PRRs are Toll-like receptors (TLRs) which are expressed on apical or basolateral membranes of IECs. Bacterial recognition by PRRs induces IECs activation, leading to the production of different cytokines which will orchestrate the course of infection ${ }^{(12,13)}$.

Some cytokines, as IL-8, IL- 6 and TNF- $\alpha$, act recruiting and activating different cells leading to a proinflammatory immune response. On the other hand, cytokines as IL-10 acts as antiinflammatory, downmodulating the immune response, an important mechanism in maintaining intestinal homeostasis ${ }^{(14)}$. The goal of this study was to evaluate interaction of invasive strains of EAEC with T84 intestinal epithelial cells and the production of cytokines.

\section{METHODS}

\section{Bacterial strains}

EAEC strains were isolated from the faeces of children under two years of age with acute diarrhea coming from the urban area of Rio de Janeiro, Brazil. Diarrhea was defined as the occurrence of one or more elimination of liquid faeces in a period of 24 hours $^{(15)}$. The prototype strain EAEC 042, isolated from children with diar- 
rhea in outbreak in Peru ${ }^{(16)}$ was included in the present study. The EAEC strains H92/3 and I49/3 were previously characterized by DNA hybridization probe or by polymerase chain reaction (PCR) for putative virulence factors of $\mathrm{EAEC}^{(15,17)}$. Adhesion assays in the intestinal cell line T84 after 6 hours of incubation was used to characterize the aggregative pattern (TABLE 1). All strains were stored at $-70^{\circ} \mathrm{C}$ in Trypticase Soy Broth (TSB, Merck) supplemented with $20 \%$ glycerol.

\section{Cell culture}

The human intestinal colon carcinoma T84 cell line (ATCC CCL248) ${ }^{(18)}$ was cultured in a 1:1 mixture of Ham F12 culture medium (Gibco-BRL) and Dulbecco's modified Eagle Minimum Essential Culture Medium (DMEM; Gibco-BRL), supplemented with 10\% Fetal Bovine Serum (FBS; Gibco-BRL), $2.5 \mathrm{mM} \mathrm{L-}$ glutamine, $50 \mu \mathrm{g} / \mathrm{mL}$ gentamicin and $2.5 \mu \mathrm{g} / \mathrm{mL}$ fungizone. The cell line was maintained at $37^{\circ} \mathrm{C}$ in $5 \% \mathrm{CO}_{2}$ atmosphere. For epithelial cell infection and intracellular persistence assays, cells were cultured in appropriate medium in 24-well plates (Nunc International, USA).

\section{Epithelial cell infection}

Infection of T84 cells with EAEC strains was performed as previously described by Harrington et al. ${ }^{(19)}$ with modifications. After confluence and polarization of cells, the wells were washed with Dulbecco's phosphate buffered saline (PBS-D) $\mathrm{pH} 7.2$, added of DMEM with $2 \%$ FBS and 1\% D-mannose.

Bacterial strains were cultured in $3 \mathrm{~mL}$ of TSB (Merck), incubated for 18 hours at $37^{\circ} \mathrm{C}$ and aliquots of $100 \mu \mathrm{L}$ standardized bacterial suspensions (approximately $10^{7} \mathrm{CFU} \mathrm{mL}^{-1}$ ) was inoculated on the cell monolayers in triplicates, then the plate was centrifuged for synchronization (Eppendorf Centrifuge 5810R, Hamburg, Germany) and incubated at $37^{\circ} \mathrm{C}$ in $5 \% \mathrm{CO}_{2}$ atmosphere for 3 hours. Subsequently, cells were washed with PBS-D, added of DMEM with $2 \%$ FBS, $1 \%$ D-mannose and $100 \mu \mathrm{g} / \mathrm{mL}$ amikacin [250 mg/mL] (Teuto, Brazil) and incubated for more 21 hours. After 24 hours of incubation, the supernatant was centrifuged and immediately stored at $-20^{\circ} \mathrm{C}$.

\section{Evaluation of cytokine production}

The cytokines IL-1 $\beta$, IL-6, IL-8, IL-10 and TNF- $\alpha$ were measured in the supernatants of infected and non-infected T84 cell by a sandwich ELISA, using a commercial kit from R\&D Systems (Wiesbaden, Germany) according to the manufacturer's instructions. The kit contains two monoclonal antibodies specific for each cytokine, one of which is biotinylated. The reaction was then developed with streptavidin-HRP using as substrate 3,3', 5,5' tetramethylbenzidine (TMB - R\&D Systems).

\section{Nitrites}

For nitric oxide (NO) assay, supernatants from T84 cultures were immediately mixed with an equal volume of Griess reagent to detect nitrites production ${ }^{(20)}$.

\section{Intracellular persistence of EAEC in T84 cells}

The evaluation of intracellular persistence in T84 cells infected with EAEC strains was performed as previously described by Pereira et al. ${ }^{(10)}$ with modifications. After infection of the epithelial cells and 24 hours of incubation the cell monolayers were washed with PBS-D followed by lysis with 1\% Triton X-100 (Riedel, Germany) in PBS-D for 30 minutes. After vigorous homogenization of each well, $200 \mu \mathrm{L}$ of the obtained lysate was diluted in ratio 10 in a 96-well plate and 10 $\mu \mathrm{L}$ aliquots of each dilution were plated in TSA medium (Merck). The plates were incubated at $37^{\circ} \mathrm{C}$ in $5 \% \mathrm{CO}_{2}$ atmosphere for 18 hours, followed by counting the colonies, obtaining the number of colony forming unit $/ \mathrm{mL}(\mathrm{CFU} / \mathrm{mL})$ of the lysate.

\section{Statistical analysis}

Intracellular persistence assays were expressed as mean \pm one standard deviation (SD) of three experiments performed independently. Cytokine levels were expressed as mean of three experiments performed independently and standard error of the mean (SEM) The statistical analysis was calculated using a one-way ANOVA followed by multiple paired comparisons with Bonferroni error correction for ELISA and Unpaired t test for persistence assay using Graph-Pad Prism Version 5.03. Statistical significance results were considered when $P<0.05$.

\section{RESULTS}

\section{Persistence of EAEC in T84 cells}

The intracellular persistence of H92/3 and I49/3 EAEC strains and the prototype 042 in T84 cells were investigated after 24 hours of incubation and survival rates were approximately $1.4 \times 10^{3}, 3.2$ $\mathrm{x} 10^{3}$ and $0.5 \times 10^{3} \mathrm{CFU} / \mathrm{mL}$, respectively. All strains were statistically significant $(0.01<P<0.05)$ when compared to non-infected T84 cells (FIGURE 1).

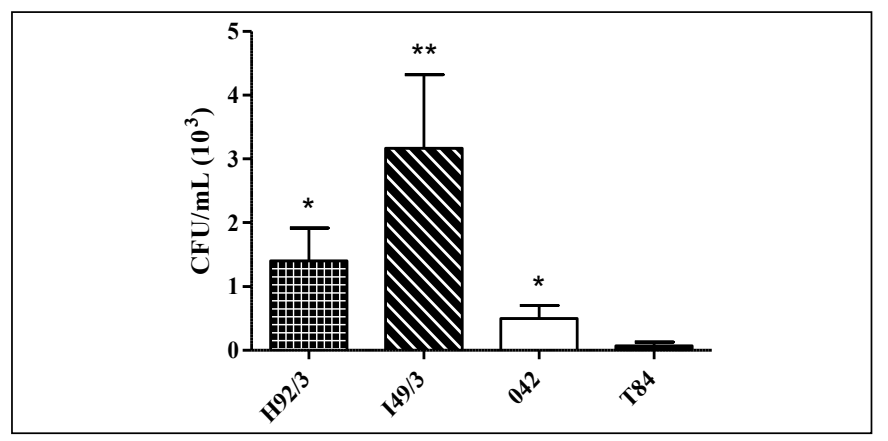

FIGURE 1. Intracellular survival of EAEC H92/3, I $49 / 3$ and 042 strains on T84 cells after 24 hours of incubation. The non-infected T84 cells were used as negative control of each experiment. Persistence assays were expressed as mean \pm one standard deviation of three experiments performed independently. Statistical analysis was performed by Unpaired t test. $* P<0.05, * * P<0.01$.

TABLE 1. Enteroaggregative Escherichia coli (EAEC), prototype strain and their serotypes, phylogenetic groups, virulence factors and adherence patterns.

\begin{tabular}{|c|c|c|c|c|}
\hline Strains & Serotype $^{\text {a }}$ & Phylogenetic Group & Virulence factors ${ }^{b}$ & Adherence Pattern ${ }^{c}$ \\
\hline $\mathrm{H} 92 / 3$ & O86:H18 & $\mathrm{D}$ & $\mathrm{pAA}^{*}, \operatorname{aggA}, \operatorname{agg} R$, aap, fyuA, irp2, pic & AA \\
\hline $\mathrm{I} 49 / 3$ & $\mathrm{O} 26: \mathrm{H} 27$ & A & pAA*, agg3A, aggR, aap, astA, irp2, pet, pic & AA \\
\hline 042 & $\mathrm{O} 44: \mathrm{H} 18$ & $\mathrm{D}$ & $\mathrm{pAA}^{*}$, aafA, aggR, aap, ast $A$, fyuA, irp 2, pet, pic & AA \\
\hline
\end{tabular}

${ }^{a} \mathrm{O}$ : somatic antigen polysaccharide; H: flagellar antigen. ${ }^{\mathrm{b}} \mathrm{pAA}$ : aggregative adherence plasmid; aggA: aggregative adherence fimbriae I; aggR: transcriptional regulator; aap: dispersin; fyuA and $i r p 2$ : genes involved in iron caption; pic: protein involved in colonization; agg $3 A$ : aggregative adherence fimbriae III; ast $A$ : aggregative heat-stabile toxin; pet: plasmid enconded toxin; aaf $A$ : aggregative adherence fimbriae II. * Detection by hybridization with DNA probe. ${ }^{c}$ AA, aggregative adherence. 


\section{Inflammatory responses of EAEC-infected T84 cells}

Confluent T84 cells were infected for 24 hours with different EAEC strains. The prototype EAEC strain 042 induced a strong production of IL-8 compared to uninfected cells $(P<0.0001)$, a chemokine for neutrophils (FIGURE 2A). The strains H92/3 and I49/3 also induced high production of IL-8 (FIGURE 2 A, $P<0.0001$ and $P<0.01$, respectively). We also evaluated the production of IL- 6 by infected T84 cells. As shown in FIGURE 2B, all EAEC strains induced significant production of IL-6 compared to non-infected T84 cells $(P<0.0001)$. Interestingly, the strain I49/3 induced high amounts of IL- 6 compared to 042 and H92/3 strains $(P<0.0001)$. In this system, we don't detect significant changes of IL- $1 \beta$ secretion, independently of different strains tested (data not shown). The TNF- $\alpha$ response was also investigated, since this cytokine is an important cellular activator. Infection by the prototype 042 and I49/3 induced significant secretion of TNF- $\alpha(P<0.01$ and $P<0.0001$, respectively) compared to uninfected T84 cells (FIGURE 2C). In our system, we did not detect significant differences of TNF- $\alpha$ levels when T84 cells were infected by H92/3 strain (FIGURE 2C). Infection by the different EAEC strains did not induce changes in the amount of IL-10 secretion by T84 cells (data not shown). In addition, we did not observe upregulation in nitric oxide (NO) secretion (data not shown), although these strains were able to induce high amounts of inflammatory cytokines (FIGURE 2).

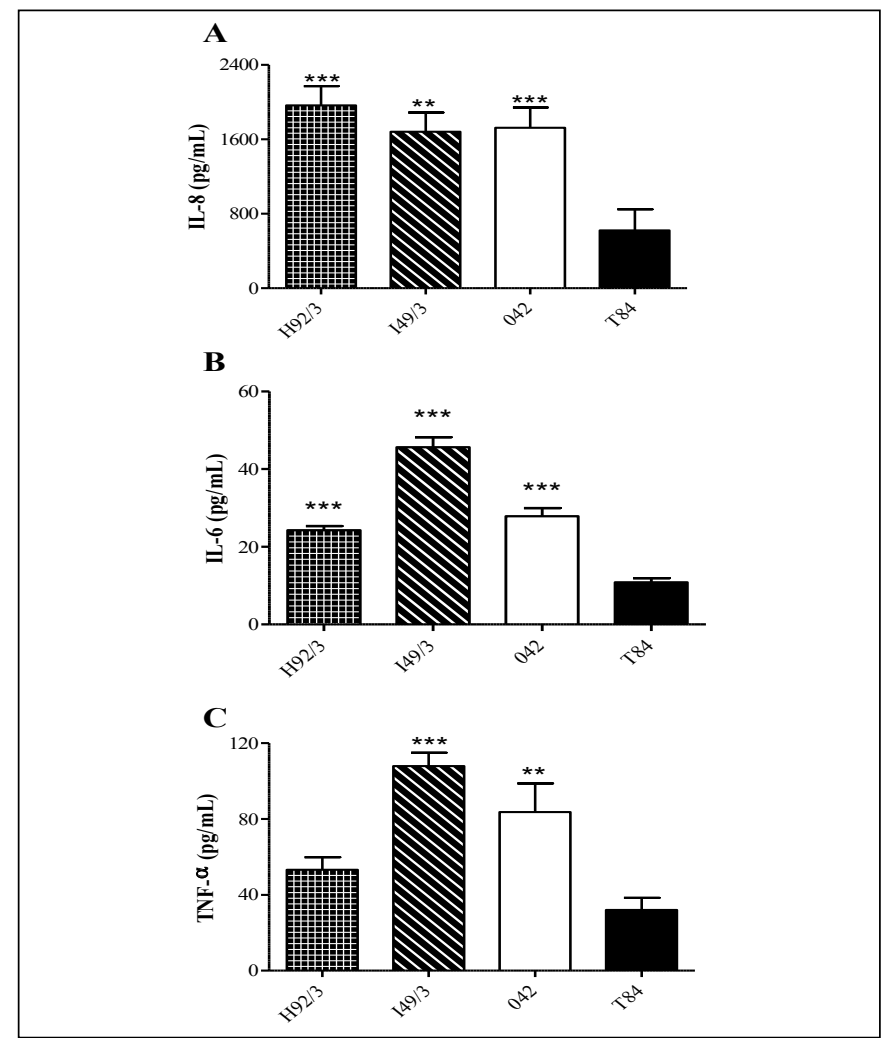

FIGURE 2. Cytokine production by infected T84 cells. T84 cells were infected with EAEC H92/3, I49/3 and 042 strains. After 24 hours of infection, supernatants were collected and tested for IL-8 (A), IL-6 (B) and TNF- $\alpha(C)$. The basal production of cytokines was measured on non-infected T84 cells. Cytokine responses were expressed as mean and SEM of three experiments performed independently. Statistical analysis was performed by one-way ANOVA followed by comparisons of pairs using Bonferroni error correction. ** $P<0.01$, *** $P<0.0001$.

\section{DISCUSSION}

Diarrhea is a leading killer of children, accounting for 9 per cent of all deaths among children under age 5 worldwide in 2015. This translates to over 1,400 young children dying each day, or about 526,000 children a year ${ }^{(21)}$. Common amongst the Diarrhoeagenic Escherichia coli (DEC) strains is the ability to colonize the intestinal mucosa, evade the immune system, multiply and cause tissue host damage ${ }^{(22)}$.

The diarrhea caused by EAEC is the result of a complex interaction pathogen-host. In different clinical settings, the diseases induced by EAEC is accompanied by activation of an inflammatory response ${ }^{(23)}$. The pathogenicity of bacteria frequently includes colonizing, adhesion of the intestinal tract and the ability to invade and persist within enterocytes ${ }^{(9)}$. A previous study in our laboratory has shown that EAEC invaded and persisted in Caco-2 and T84 cells in extended periods of incubation, 6 to 72 hours $^{(10)}$. In the present study, intracellular persistence assays showed that the same EAEC strains are able to survive in T84 cells after 24 hours of incubation. The strains tested had distinct genotypes with a wide range of virulence factors and we noticed that the strain I49/3 which contain the aggregative adherence fimbriae $\operatorname{agg} 3 \mathrm{~A}$ gene (AAF/III) showed higher persistence levels ${ }^{(10)}$.

The mucosal surface is an important barrier to pathogens, and it can be represented by IECs in the gastrointestinal tract. Also, IECs are able to induce an inflammatory response upon infection, recruiting and activating immune cells, as neutrophils and $\mathrm{T}$ lymphocytes ${ }^{(12,13)}$.

IECs respond to many inflammatory stimuli by secretion of proinflammatory cytokines and chemokines such as IL- $8{ }^{(24)}$. IL-8 is one of the most important chemokines that recruits neutrophils to the site of infection ${ }^{(25)}$. According to our results, Harrington et al. ${ }^{(19)}$ also observed upregulation of IL-8 gene in 042-infected non-polarized T84 cells. Upregulation of IL-8 by infected IECs has also been reported by others, using different systems: the hemorrhagic coli pilus of enterohemorrhagic Escherichia coli (EHEC) ${ }^{(26)}$, enteropathogenic Escherichia coli (EPEC) $)^{(22,27)}$ and EAEC ${ }^{(4,11,19,22,24)}$.

Another proinflammatory cytokine is IL-6, a potent inducer of acute-phase proteins and is also known to upregulate $\mathrm{T}$ and $\mathrm{B}$-cell maturation. Besides, TNF- $\alpha$ acts on endothelial cells upregulating adhesion molecules, enabling cells to migrate into inflammatory foci and also activates neutrophils, increasing their degranulation and respiratory burst, a potent microbicidal mechanism ${ }^{(25)}$. In our study T84 cells infected with EAEC strains produced IL-8, IL-6 and TNF- $\alpha$.

The H92/3 and I49/3 strains and the prototype strain EAEC 042 have the AAFs and the transcriptional regulator agg $\mathrm{R}$, which could explain the high production of IL-8, IL- 6 and TNF- $\alpha$ by T84 infected cells, as previously observed with different EAEC also expressing $\operatorname{agg} \mathrm{R}^{(28)}$. Cennimo et al. ${ }^{(28)}$ used a human intestinal adenocarcinoma cell line, HCT-8, to determine genes and cytokine responses of EAEC isolates from adult patients presenting to an urgent-care clinic in the USA. The authors inferred that aggRpositive EAEC elicited higher levels of IL-6, IL-8 and TNF- $\alpha$ compared with aggR-negative EAEC. Furthermore, individuals infected with EAEC containing the gene $\operatorname{agg} R$ in conjunction with the genes aap, aat $A$, ast $A$, pet and/or set were more likely to have markers of inflammation present in their stool examination. These findings suggest that one or more of these genes may be a marker for virulence and are associated with inflammation during diarrheal 
illness $^{(28)}$. The strains used in the present study have at least two at most four of these genes, ratifying our results.

Coordinated expression and upregulation of IL-8, IL-6, TNF- $\alpha$ and others proinflammatory cytokines were observed by Bandyopadhaya et al. ${ }^{(29)}$ in the intestinal epithelial cell line Int407 upon Vibrio cholerae infection. These proinflammatory cytokines also showed increased expression in T84 cells, except for IL-6. Medeiros et al. ${ }^{(30)}$ showed that EAEC 042 strain induced IL-8 and TNF- $\alpha$ expression, but not IL-6, and reduced TGF $\beta$ expression, in intestinal epithelial cell line IEC-6 in the early stages (180 min) of infection. Recently, Gupta et al. ${ }^{(11)}$ studying EAEC with different AAF types in duodenal biopsies using in vitro organ culture (IVOC) observed an increased expression of IL-1 $\beta$, IL-8, IL-6 and TNF- $\alpha$. Our results were similar, although we didn't detect significant changes in IL- $1 \beta$ secretion.

The nitric oxide (NO), that is synthesized in large amounts by the inducible NO synthase (iNOS) under pathophysiologic conditions acts as a potent effector of the innate immune system, which plays a major role in the development of inflammation and in the fight against pathogens ${ }^{(31)}$. It was observed NO induction by enteropathogenic bacteria as Salmonella Dublin ${ }^{(32)}$ and enterohemorrhagic Escherichia coli (EHEC) ${ }^{(31)}$. Although we did not observe NO production by T84 cells infected with EAEC in our system, it may also be possible that the bacteria inhibited its production as an escape mechanism of the immune system. Further investigation would be necessary in order to elucidate this question.

Here, we reinforced that infection together with intracellular persistence of EAEC strains induce a proinflammatory response leading to intestinal inflammation that could result in diarrhea and even death.

\section{Authors' contribution}

Braga RLL: survey execution, writing of text. Pereira ACM: survey execution. Ferreira AF: survey execution. Rosa ACP: project coordinator, designed the research, Pereira-Manfro WF: designed the research, writing of text.

Braga RLL, Pereira ACM, Ferreira AF, Rosa ACP, Pereira-Manfro WF. A persistência intracelular de Escherichia coli enteroagregativa induz a secreção de citocinas pró-inflamatórias em células epiteliais intestinais T84. Arq Gastroenterol. 2018;55(2):133-7.

RESUMO - Contexto - A competência de Escherichia coli enteroagregativa (EAEC) para aderir ao epitélio intestinal do hospedeiro é um papel fundamental para a colonização e o desenvolvimento da doença. Os genes de virulência são cruciais para a patogenicidade de EAEC durante a aderência, a internalização e a persistência no hospedeiro. A grande maioria dos encontros de antígenos em um hospedeiro ocorre na superfície do intestino, que é considerada parte da imunidade inata da mucosa. As células epiteliais intestinais (IECs) podem ser ativadas por micro-organismos e induzir uma resposta imune. Objetivo - O presente estudo investigou a interação de cepas invasoras de EAEC com a linhagem celular epitelial intestinal T84 em relação a invasão bacteriana, a persistência e a produção de citocinas. Métodos - Avaliamos a persistência intracelular de cepas invasoras de EAEC (H92/3, I49/3 e o protótipo 042) e a produção de citocinas por ELISA "sanduíche" em células T84 após 24 horas de infecção. Resultados - As taxas

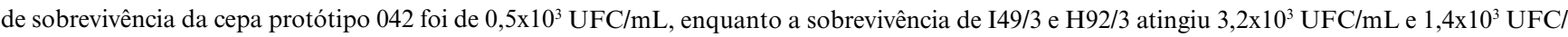
$\mathrm{mL}$, respectivamente. A infecção com todas as cepas EAEC testadas induziu quantidades significativas de IL-8, IL-6 e TNF- $\alpha$ em comparação com células T84 não infectadas. Conclusão - Estes dados mostraram que a infecção por EAEC invasoras induzem uma resposta imune pró-inflamatória em células epiteliais intestinais T84.

DESCRITORES - Infecções por Escherichia coli. Mucosa intestinal. Células epiteliais. Citocinas.

\section{REFERENCES}

1. Jensen BH, Olsen KEP, Struve C, Krogfelt KA, Petersen AM. Epidemiology and clinical manifestations of enteroaggregative Escherichia coli. Clin Microbiol Rev. 2014;27:614-30

2. Regua-Mangia AH, Gomes TAT, Vieira MAM, Andrade JRC, Irino K, Teixeira LM. Frequency and characteristics of diarrhoeagenic Escherichia coli strain isolated from children with and without diarrhoea in Rio de Janeiro, Brazil. Journ Infect. 2004;48:161-7.

3. Araujo JM, Tabarelli GF, Aranda KRS, Fabbricotti SH, Fagundes-Neto U, Mendes CMF, Scaletsky ICA. Typical enteroaggregative and atypical enteropathogenic types of Escherichia coli are the most prevalent diarrhea-associated pathotypes among Brazilian children. J Clin Microbiol. 2007;45:3396-9.

4. Dias RC, Dos Santos BC, Dos Santos LF, Vieira MA, Yamatogi RS, Mondelli AL, et al. Diarrheagenic Escherichia coli pathotypes investigation revealed atypical enteropathogenic $E$. coli as putative emerging diarrheal agents in children living in Botucatu, São Paulo State, Brazil. APMIS. 2016;124:299-308.

5. Navarro-Garcia F \& Elias WP. Autotransporters and virulence of enteroaggregative E. coli. Gut Microbes. 2011;2:13-24.

6. Estrada-Garcia T \& Navarro-Garcia F. Enteroaggregative Escherichia coli pathotype: a genetically heterogeneous emerging foodborne enteropathogen. FEMS Immunol Med Microbiol. 2012;66:281-98.

7. Kaur P, Chakraborti A, Asea A. Enteroaggregative Escherichia coli: an emerging enteric food borne pathogen. Interdiscip Perspect Infect Dis. 2010:1-10.

8. Nataro JP, Hicks S, Phillips AD, Vial PA, Sears CL. T84 cells in culture as a model for enteroaggregative Escherichia coli pathogenesis. Infect Immun. $1996 ; 64: 4761-8$
9. Abe CM, Knutton S, Pedroso MZ, Freymüller E, Gomes, TAT. An enteroaggregative Escherichia coli strain of serotype O111:H12 damages and invades cultured T84 cells and human colonic mucosa. FEMS Microbiol Lett. 2001;203:199-205.

10. Pereira ACM, Britto-Filho JD, Jose de Carvalho J, de Luna MDG, Rosa ACP. Enteroaggregative Escherichia coli (EAEC) strains enter and survive within cultured intestinal epithelial cells. Microb Pathog. 2008;45:310-4.

11. Gupta D, Sharma M, Sarkar S, Thapa BR, Chakraborti A. Virulence determinants in enteroaggregative Escherichia coli from North India and their interaction in in vitro organ culture system. FEMS Microbiol Lett. 2016;363(17). pii: fnw189.

12. Kawai T, Akira S. Toll-like receptors and their crosstalk with other innate receptors in infection and immunity. Immunity. 2011;34:637-50.

13. Kinnebrew MA, Pamer EG. Innate immune signaling in defense against intestina microbes. Immunol Rev. 2012;245:113-31.

14. Onyiah JC, Colgan SP. Cytokine responses and epithelial function in the intestina mucosa. Cell Mol Life Sci. 2016;73:4203-12.

15. Rosa ACP, Mariano AT, Pereira MAS, Tibana A, Gomes TAT, Andrade JRA Enteropathogenicity markers in Escherichia coli isolated from infants with acute diarrhea and healthy controls in Rio de Janeiro, Brasil. J Med Microbiol. 1998;47:781-90.

16. Nataro JP, Scaletsky ICA, Kaper JB, Levine MM, Trabulsi LR. Plasmid-mediated factors conferring diffuse and localized adherence of enteropathogenic Escherichia coli. Infect Immun. 1985;48:378-83.

17. França FLS, Wells TJ, Browning DF, Nogueira RT, Sarges FS, Pereira AC, et al. Genotypic and phenotypic characterisation of enteroaggregative Escherichia coli from children in Rio de Janeiro, Brazil. PLoS One. 2013;8:e69971. 
18. Murakami H \& Masui H. Hormonal control of human colon carcinoma cell growth in serum-free medium. Proc Natl Acad Sci USA. 1980;77:3464-8.

19. Harrington SM, Strauman MC, Abe CM, Nataro JP. Aggregative adherence fimbriae contribute to the inflammatory response of epithelial cells infected with enteroaggregative Escherichia coli. Cell Microbiol. 2005;7:1565-78.

20. Green LC, Wagner DA, Glogowski J, Skipper PL, Wishnok JS, Tannenbaum SR. Analyis of nitrate, nitrite, and $[15 \mathrm{~N}]$ nitrate in biological fluids. Anal Biochem. 1982;126:131-8.

21. Unicef.org [homepage on the Internet]. UNICEF Data: Monitoring the Situation of Children and Women. [updated 2017 Feb, cited 2017 Jun 8, 2017]. Available from: https://data.unicef.org/topic/child-health/diarrhoeal-disease/.

22. Edwards LA, Bajaj-Elliott M, Klein NJ, Murch SH, Phillips AD. Bacterial-epithelial contact is a key determinant of host innate immune responses to enteropathogenic and enteroaggregative Escherichia coli. Plos One. 2011;6(10):e27030.

23. Rocha-Ramírez LM, Hernández-Chiñas U, Baños-Rojas D, Xicohtencatl-Cortés J, Chávez-Berrocal ME, Rico-Rosillo G, et al. Pet serine protease from enteroaggregative Escherichia coli stimulates the inflammatory response activating human macrophages. BMC Microbiol. 2016;16:158

24. Khan MA, Kang J, Steiner TS. Enteroaggregative Escherichia coli flagellin-induced interleukin-8 secretion requires Toll-like receptor 5-dependent p38 MAP kinase activation. Immunol. 2004;112:651-60.

25. Borish LC \& Steinke JW. Cytokines and chemokines. J Allergy Clin Immunol. 2003; 111:S460-75.
26. Ledesma MA, Ochoa SA, Cruz A, Rocha-Ramírez LM, Mas-Oliva J, Eslava CA, Girón JA, Xicohtencatl-Cortes J. The hemorrhagic coli pilus (HCP) of Escherichia coli $\mathrm{O} 157: \mathrm{H} 7$ is an inducer of proinflammatory cytokine secretion in intestinal epithelial cells. Plos One. 2010;5:e12127.

27. Zhou X, Girón JA, Torres AG, Crawford JA, Negrete E, Vogel SN, Kaper JB. Flagellin of enteropathogenic Escherichia coli stimulates interleukin-8 production in T84 cells. Infect Immun. 2003;71:2120-9.

28. Cennimo D, Abbas A, Huang DB, Chiang T. The prevalence and virulence characteristics of enteroaggregative Escherichia coli at an urgent-care clinic in the USA: a case-control study. J Med Microbiol. 2009;58(Pt 4):403-7.

29. Bandyopadhaya A, Sarkar M, Chaudhuri K. Transcriptional upregulation of inflammatory cytokines in human intestinal epithelial cells following Vibrio cholerae infection. FEBS J. 2007;274:4631-42.

30. Medeiros P, Bolick DT, Roche JK, Noronha F, Pinheiro C, Kolling GL, et al. The micronutrient zinc inhibits EAEC strain 042 adherence, biofilm formation, virulence gene expression, and epithelial cytokine responses benefiting the infected host. Virulence 2013;4:624-33.

31. Vareille M, Rannou F, Thélier N, Glasser AL, de Sablet T, Martin C, Gobert AP. Heme oxygenase-1 is a critical regulator of nitric oxide production in enterohemorrhagic Escherichia coli-infected human enterocytes. J Immunol. 2008; 180:5720-6.

32. Cornish AS, Jijon H, Yachimec C, Madsen KL. Peroxynitrite enhances the ability of Salmonella dublin to invade T84 monolayers. Shock. 2002;18:93-6. 